\title{
Entrepreneurship Traits of Science, Engineering and Technology (SET) Students
}

\author{
Elma van der Lingen \\ elma.vanderlingen@up.ac.za \\ Gerhard van Niekerk \\ gerhardvn@gmail.com
}

\begin{abstract}
Department of Engineering and Technology Management, Graduate School of Technology Management, University of Pretoria, South Africa Corresponding author: elma.vanderlingen@up.ac.za
\end{abstract}

\begin{abstract}
Entrepreneurship studies and education courses have increased significantly with the realisation of their importance for economic growth. Entrepreneurship courses are no longer only offered in business schools and faculties of economic and management sciences. They are increasingly being incorporated into natural sciences and engineering faculties. The aim of this study is to determine the enterprising tendency of science, engineering and technology (SET) students with the General Enterprising Tendency (GET) test developed by Dr Sally Caird. SET students have an aboveaverage enterprising tendency, which indicates that they are likely to be enterprising in some way, but most likely through intrapreneurship by being part of a group within a corporate environment. The first degree (BEng, BSc or BTech) of SET students appears to have no influence on their enterprising tendency. Male students have a higher enterprising tendency than female students, and males in the BTech degree revealed a significantly higher need for autonomy than females. White students have a higher tendency to display entrepreneurial traits, such as need for autonomy, calculated risk-taking and internal locus of control, whereas black students display a higher need for achievement. The aim of this study is to structure technopreneurship courses in order to provide more effective training for SET students.
\end{abstract}

Keywords: Entrepreneurship, traits, tendencies, technopreneurs, science students, engineering students, technology students, SET students, gender, ethnical group, GET test 


\section{INTRODUCTION}

Entrepreneurship has become increasingly important to enhance a country's economy. This has also resulted in various academic departments offering courses in entrepreneurship. Entrepreneurship is no longer only offered by business schools and faculties of economic and management sciences, but also by various natural sciences and engineering faculties.

Technology entrepreneurs, also known as technopreneurs, are important in newventure initiations, as they can identify business opportunities in the scientific and engineering space (Wickham, 1998). As the modern world is rapidly changing, it presents a magnitude of new technologies that can be developed into new ventures. These new developments not only demand technical skills from natural sciences and engineering students, but also business and entrepreneurial skills (Refaat, 2009).

The aim of this study is to determine the enterprising tendency of science, engineering and technology (SET) students and to compare these results with those of students in other disciplines and professions. The study will further explore whether there is a relationship between the enterprising tendency of SET students and their first scientific degree, gender and ethnic group. The future aim with continuing this study will be to structure technopreneurship courses in order to provide more effective training for SET students.

The paper includes a literature review on the personality traits of entrepreneurs and how enterprising tendencies can be measured. The methodology, results and discussion, and conclusion follow.

\section{LITERATURE}

\section{Entrepreneur}

According to Hébert and Link (1989) the pre-classical entrepreneur, Richard Cantillon (1680-1734), was the first person to use the term "entrepreneur". Cantillon considered the entrepreneur to be the central economic player of the three groups of actors in the economy, namely landowners, employees and risk-taking entrepreneurs. The entrepreneur connects economic factors and allows economic exchanges to occur (Van Praag, 1999). According to Wennekers and Thurik (1999), three main traditions 
characterise entrepreneurs. These traditions have the same origin, but emphasise different aspects of entrepreneurship. The German tradition of Baumol, Schumpeter and Von Thunen focuses on entrepreneurs as forces of instability and creative destruction. The entrepreneur is seen as a person who gets things done and is an economic innovator. The neoclassical tradition of Marshall, Knight and Schultz stresses the role of the entrepreneur in establishing economic stability and decisionmaking. Menger, Von Mises and Kirzner of the Austrian tradition, concentrate on the entrepreneur's ability to perceive profitable opportunities (Wennekers and Thurik, 1999).

There is no consensus among researchers on an exact definition of entrepreneurship. For example, entrepreneurship is seen as the creation of new value, which includes recognising opportunities, taking responsibility and making decisions, displaying total commitment to a venture, the willingness to take calculated risks and the creative skill needed to get the required resources (Kirby, 2004).

Although the term "entrepreneur" has been known for many centuries, studies on entrepreneurship, as well as the development of entrepreneurship education courses, increased significantly as people realised the importance of the discipline for economic growth. However, entrepreneurship is a relatively new field in management studies and has only been widely studied since the 1980s (Shane \& Venkataraman, 2000).

\section{Entrepreneurship education}

Drucker (1985) states that "most of what you hear about entrepreneurship is wrong. It's not magic, it is not mysterious and it has nothing to do with genes. It's a discipline and, like any discipline, it can be learned". Today, entrepreneurship education is lectured in various disciplines, such as business, management, and science and engineering studies. These studies do not just encourage entrepreneurship, they also encourage the intrapreneurship of employees in corporate environments. It is widely accepted that entrepreneurial processes can be taught these days (Kuratko, 2005) and universities play an important role in encouraging entrepreneurship, as they are involved in the creation of opportunity-based enterprises (Autio, 2005).

Besides imparting knowledge, formal education can have a profound impact on 
influencing a student's personality, which develops his or her skills and shapes his or her character and value system (Jyohti, 2009). Keat, Yeng and Meyer (2011) state that entrepreneurship education is the "pedagogical process involved in the encouragement of entrepreneurial activities, behaviours and mindsets". They also state that universities are ideally placed to promote entrepreneurship and can influence a student's career choice of being self-employed or working as an employee. Governments worldwide have seen the importance of entrepreneurship education (knowledge and skills) and actively promote entrepreneurship education in schools, colleges and universities to create an enterprising and innovative society (Kirby, 2004).

Entrepreneurship education is applied to foster economic growth and innovation, and the evaluation of these entrepreneurship programmes has become increasingly crucial to the process of improving the outcome. Huber, Sloof and Van Praag (2014) conclude that the evaluation studies on entrepreneurship education conducted so far have indicated modest effects, as well as contradictory results. Martin, McNally and Kay (2013) conducted a meta-analysis of 42 entrepreneurship education and training (EET) papers between 1979 and 2011, and state that there are strong relationships between EET, entrepreneurship-related human capital assets and entrepreneurship outcomes. Their study further revealed that academic EET interventions result in stronger outcomes than EET interventions that are focused on training. Evidence of heterogeneity in their correlations results from, among other things, methodology weaknesses in published studies.

Entrepreneurship programmes vary in scope and intensity, as do the material and teaching methods (Kirby, 2004; Shane \& Venkataraman, 2000). Some studies focus on the content and manner in which entrepreneurship programmes should be taught (Van Vuuren \& Nieman, 1999; Nieuwenhuizen \& Groenewald, 2008; Pretorius, 2008; Karlsson \& Moberg, 2013). Mwasalwibe (2010) found that there is a shift from a startup to an attitude-changing perspective within entrepreneurship education, whereas Carey and Matlay (2010) looked into the characteristics of creative discipline education and ideas assessment. Radipere (2012) suggests that entrepreneurship education should include the use of interactive methods, as well as providing students with simulations to develop decision-making and analytical skills. Although 
Warhuus and Basaiawmoit (2014) aimed to evaluate how technopreneurship programmes are developed and designed at different science, technology, engineering and mathematical (STEM) institutions, they found that "diversity in effective and successful programmes uncovers strong interdependencies between programme design and inception, and the programme developers".

Many entrepreneurship courses and handbooks focus on the screening of potential business opportunities according to specific frameworks, compiling a business plan, intellectual property (IP) rights and financial assessment. While opportunity recognition is important (Shane \& Venkataraman, 2000), students are not always equipped to undertake a self-evaluation to determine if they would want to attempt an entrepreneurial career or utilise a business opportunity (Mazzarol, 2007). Mazzarol's diagnostic study on Master of Business Administration (MBA) students, which made use of the General Enterprising Tendency (GET) test, showed that students can be made aware of their own entrepreneurial capacity. Mazzarol further states that environmental forces have a positive or negative influence on people's entrepreneurial traits.

Souitaris, Zerbinati and Al-Laham (2007) draw on the theory of planned behaviour (Ajzen, 1991) when they investigate whether or not a student's intention to start a business would increase after participating in an entrepreneurship course. Since starting a business is a planned event, increased intention would translate into more newly created businesses. The study found that participating in an entrepreneurship course increased the intention of self-employment through inspiration and not knowledge gained.

In psychology literature, intention was proven to be the best predictor of planned behaviour. Entrepreneurship is a typical example of planned intentional behaviour (Souitaris et al., 2007). Kautonen, Van Gelderen and Tornikoski (2013) use the theory of planned behaviour to predict entrepreneurial behaviour prior to the onset of any observable action. The best way to predict planned behaviour, such as entrepreneurship, is "by observing intentions towards behaviour - not by attitudes, beliefs, personality or mere demographics" (Krueger, Reilly \& Carsrud, 2000). 


\section{Personality traits of entrepreneurs}

Most entrepreneurs share some common psychological trait, which is usually a good predictor of entrepreneurial behaviour (Koh, 1996). An entrepreneur is further not defined by a single trait or characteristic, but rather by a configuration of traits that distinguish potential entrepreneurs from those who are not interested in setting up new ventures (Mueller \& Thomas, 2001). Some common traits of entrepreneurs include the following:

- $\quad$ The need for achievement has been seen as an entrepreneurial trend ever since it was introduced by McClelland, Atkinson, Clark and Lovell (1953). Their definition of the need to achieve is "an arousal when there is competition with a standard of excellence in situations where performance may be assessed for success or failure". Cromie (2000) and Caird (1991a) associate the need for achievement with self-awareness, planning initiative, responsibility, decision-making, problem-solving, innovation, risk-taking, energy, determination and motivation. It is one of the most studied personality traits in entrepreneurship (Demirci, 2013) and has been linked to successful business creation (Mueller \& Thomas, 2001). In conjunction with the need to achieve, entrepreneurs generally have a low need for power.

- The important role of creativity in entrepreneurship is probably the earliest known trait of entrepreneurship (Schumpeter, 1951). Creativity and innovation in entrepreneurship refer to the ability to create, develop new ideas, investigate and experiment with new ideas, find new market opportunities, and improve existing products and services to provide new value. It is the central driving force behind both innovation and entrepreneurship (Demirci, 2013). Innovation in entrepreneurship is the "process that turns an invention into a marketable product" (Gabor, 1970). Being innovative is the ability and desire to create new ways of doing business or improving existing ways.

- $\quad$ Propensity for risk-taking is the likelihood of making decisions in an uncertain environment (Koh, 1996). It is evident from multiple authors that entrepreneurs prefer to operate in environments where they have some experience and control to increase the success of the decisions they make despite the uncertainty in which they have to operate (Cromie, 2000; Koh, 
1996). Entrepreneurs generally take risks in areas where they have some degree of control or when they have experience in running a business (Nieuwenhuizen \& Groenewald, 2006).

- $\quad$ Self-belief is a key characteristic of successful entrepreneurs (Koh, 1996). This is also important in assisting them to build relationships with other people and strengthens their independence (Mueller \& Thomas, 2001).

- Rotter (1966) created the concept of "locus of control". An internal locus of control is defined as a person's positive perception of his or her ability to control and influence his or her environment and circumstances to create the desired outcomes for his or her undertakings through ability, skills or effort (Mueller \& Thomas, 2001). Entrepreneurs do not believe that luck, fate or other external forces determine how successful they are going to be, but that they personally determine their success.

- Associated with an internal locus of control is the desire for independence and autonomy. Entrepreneurs desire independence that can only be found in their own business, which provides them with control and economic self-reliance (Cromie, 2000). Entrepreneurs value their autonomy and independence very highly (Kirby, 2004).

- Tolerance for ambiguity is the entrepreneur's ability to handle all the uncertainties that surround having his or her own business. People with a high tolerance for ambiguity would be comfortable working to overcome this ambiguity in order to reach the goals they have set for themselves and their business (Koh, 1996).

\section{Measuring enterprising tendency}

Enterprising tendency measurements should consider the most significant entrepreneurial characteristics, motivations and attitudes, since entrepreneurs are not a homogenous group. Very few formalised evaluation tools of enterprising tendency have been developed. A tool that can be used for such a measurement is the GET test, which was developed by Dr Sally Caird (1991a; 1991b; 1993; 2006; 2014).

The GET test was developed from the following psychometric tests:

- The Thematic Apperception Test (TAT) (Murray, 1943), which measures 
achievement.

- The Edwards Personal Preference Schedule (EPPS) (Edwards, 1959), which measures autonomy.

- Honey and Mumford's Measure of Learning Styles (Mumford \& Honey, 1992) and Jackson's Personality Inventory (Jackson, 1976), which both measure risk-taking.

- $\quad$ The Myers-Briggs Type Indicator (MBTI) (Briggs-Myers \& McCaulley, 1985), which measures introversion versus extroversion, intuition versus sensation, thinking versus feeling, and judging versus perception.

GET is a testing tool that evaluates a person's views on entrepreneurial attributes and measures the following five characteristics that are found in successful entrepreneurs: the need for achievement, the need for autonomy, an internal locus of control, a creative tendency and risk-taking. The test contains 54 statements to which the respondents have to indicate whether they agree or disagree. Subfields are scored individually and a total score can be calculated. The average score for the test is 36 . Subfields consist of either 12 or six items. Both the GET test (Stormer \& Kline, 1999) and the tests on which it is based (Caird, 1991a; 1993) have been validated by multiple researchers. Stormer and Kline (1999) have indicated that the test is reliable and credible, as shown by an overall Cronbach's alpha rating of 0.86 for the test yield. Caird's findings are still valid today, as shown by Liñán and Chen (2009), who found a shortage of standardised, validated psychometric tests for enterprising tendencies, despite an increase in the volume of research into enterprising tendencies.

Multiple papers present results obtained by utilising the GET test on different populations. For example, Caird (1991b) performed a study with business owners, managers, teachers, nurses, civil servants and lecturers, while Stormer and Kline (1999) performed the GET test on a sample of new and successful business owners. A recent study by Ishiguro (2014) made use of the GET2 test in a study on Japanese high-school students. Mazzarol (2007) studied Australian MBA students, Kirby and Ibrahim (2010) provided some comparative values obtained with the GET test from Egyptian and British management students, Sethu (2012) performed a study on 
students studying engineering, hotel management, management, pharmacology and medicine at Manipal University in Karnataka, and Demirci (2013) described a comparative study between Canadian and Turkish students enrolled in business management courses.

These studies further found that the GET test appears to have a criterion and convergent validity, and has good internal consistency. Cromie (2000) suggests that the test requires further study to verify its psychometric properties. He found a positive correlation between the subfields of the test, as well as a strong correlation with the test total. Stormer and Kline (1999) found that, although the test is sufficient academically and a reliable measure of entrepreneurial intent, it is a poor measure of business success. Mazzarol (2007) concluded that the test has potential for the assessment of enterprising tendencies and entrepreneurial orientation, but does not determine whether or not the person being tested is an entrepreneur.

\section{METHODOLOGY}

\section{General Enterprising Tendency test}

The GET test (Caird, 1991) is the primary measuring instrument used in this study. It is employed to determine the level of students' entrepreneurial tendencies. These tendencies (achievement, locus of control, need for autonomy, creative tendency and calculated risk-taking) are measured using questions from existing psychometric tests (Caird, 1991).

In addition to the primary research questions, the researcher also captured profile information, such as gender, ethnic group and first scientific degree. The last variable is students' perception of the accuracy of the GET test, as the students receive immediate feedback on the test results and have an opportunity to rate their perceived accuracy of the test.

\section{Population and sample}

The survey population comprised students from the Graduate School of Technology Management (GSTM) at the University of Pretoria in South Africa. The GSTM students were honours students enrolled in the engineering management section of 
the Technological Entrepreneurship module. All GSTM honours students have already completed a first degree in engineering (BEng), science (BSc) or technology (BTech). In South Africa, the BEng degree (four years) and BSc degree (three years) are undertaken at traditional universities. A BTech degree (four years) is more practice orientated compared to the academically orientated BEng and BSc degrees. BTech degrees are obtained from universities of technology or comprehensive universities (an amalgamation of traditional and comprehensive universities). The population/sample is referred to as SET students. The participants are potential entrepreneurs and not practising entrepreneurs. Ethical approval was obtained before the research was conducted.

The sample of this survey was self-selected. The researcher had no direct access to the test population and had to rely on the students' willingness to respond to an email invitation. The students were surveyed directly after completing the module and before writing the final examination.

The data for the study was collected through the online survey tool Google Forms. A link to the online survey was included in the invitation email. Google Forms provides feedback to the test respondents on their GET test scores. A web-based survey tool has many advantages. It is easy to survey a large population, reduces time and cost, and it is easy to tabulate the results (McMillan \& Schumacher, 2006). According to Welman, Kruger and Mitchell (2005), all survey-type research would fall into the nonexperimental research category, since there is no planned intervention.

To validate the differences between the test groups, statistical analyses of the captured data were performed. Averages and standard deviations were computed to allow for comparisons of the data from the groups. Students' Microsoft Excel t-tests were used to determine if the differences in the data were statistically significant. The t-test uses a two-tailed distribution with a two-sample equal variance.

The researchers aimed to find answers to the following research questions:

- $\quad$ Do SET students have an above-average enterprising tendency?

- How does the enterprising tendency of SET students compare with published data from other studies on students and professions?

- Is the respondent's enterprising tendency related to his or her first scientific 
degree (BEng, BSc or BTech)?

- Does gender influence enterprising tendency?

- Do ethnic groups have an influence on enterprising tendency?

- What is the students' perceived accuracy of the GET test?

\section{RESULTS AND DISCUSSION}

The response rate was $86 \%$, with 189 students responding out of a population of 220. The results are presented according to the seven research questions.

\section{Do SET students have an above-average enterprising tendency?}

The data presented in Table 1 is according to the GET test's five entrepreneurship tendencies: need for achievement, need for autonomy, creative tendency, calculated risk-taking and internal locus of control. The maximum GET score and the GET averages shown in Table 1 are adapted from Caird (1991). The results show that the students have an overall enterprising tendency score of 40 , which is above average. This score indicates that respondents are more likely to work as intrapreneurs in an organisational team. However, there is a strong tendency to start an own venture, but stronger independent leadership qualities need to be cultured (Caird, 2014). A GET score of 44 and higher indicates a strong possibility that the respondent will start a venture and manage projects. Within the SET group, above-average results for four of the five subfields were obtained. In the fifth subfield, "need for autonomy", the actual average was 3.26 compared to the average GET score of 
Table 1: The means and standard deviations for SET students based on enterprising tendency measurements

\begin{tabular}{|c|c|c|c|c|c|c|}
\hline $\begin{array}{l}\text { Enterprising } \\
\text { tendency }\end{array}$ & First degree & No & $\begin{array}{l}\text { Maximum } \\
\text { GET score }\end{array}$ & $\begin{array}{c}\text { Average } \\
\text { GET } \\
\text { score }\end{array}$ & $\begin{array}{l}\text { Actual } \\
\text { mean } \\
\text { score }\end{array}$ & $\begin{array}{l}\text { Standard } \\
\text { deviation }\end{array}$ \\
\hline \multirow{4}{*}{ Total GET score } & BEng & 47 & \multirow{4}{*}{54} & \multirow{4}{*}{37} & 40.81 & 5.58 \\
\hline & BSc & 28 & & & 38.36 & 5.42 \\
\hline & BTech & 114 & & & 40.07 & 4.91 \\
\hline & Total & 189 & & & 40.00 & 5.19 \\
\hline \multirow{4}{*}{$\begin{array}{l}\text { Need for } \\
\text { achievement }\end{array}$} & BEng & 47 & \multirow{4}{*}{12} & \multirow{4}{*}{9} & 9.83 & 1.75 \\
\hline & $\mathrm{BSc}$ & 28 & & & 9.71 & 1.49 \\
\hline & BTech & 114 & & & 10.07 & 1.36 \\
\hline & Total & 189 & & & 9.96 & 1.48 \\
\hline \multirow{4}{*}{ Need for autonomy } & BEng & 47 & \multirow{4}{*}{6} & \multirow{4}{*}{4} & 3.74 & 1.36 \\
\hline & BSc & 28 & & & 2.93 & 1.33 \\
\hline & BTech & 114 & & & 3.14 & 1.32 \\
\hline & Total & 189 & & & 3.26 & 1.35 \\
\hline \multirow{4}{*}{ Creative tendency } & BEng & 47 & \multirow{4}{*}{12} & \multirow{4}{*}{8} & 9.62 & 1.55 \\
\hline & BSC & 28 & & & 8.71 & 2.07 \\
\hline & BTech & 114 & & & 8.82 & 1.84 \\
\hline & Total & 189 & & & 9.00 & 1.83 \\
\hline \multirow{4}{*}{ Calculated risk-taking } & BEng & 47 & \multirow{4}{*}{12} & \multirow{4}{*}{8} & 9.04 & 1.78 \\
\hline & BSC & 28 & & & 8.50 & 1.50 \\
\hline & BTech & 114 & & & 9.09 & 1.70 \\
\hline & Total & 189 & & & 8.99 & 1.70 \\
\hline \multirow{4}{*}{$\begin{array}{l}\text { Internal locus of } \\
\text { control }\end{array}$} & BEng & 47 & \multirow{4}{*}{12} & \multirow{4}{*}{8} & 8.57 & 1.66 \\
\hline & BSC & 28 & & & 8.50 & 1.97 \\
\hline & BTech & 114 & & & 8.96 & 1.58 \\
\hline & Total & 189 & & & 8.79 & 1.67 \\
\hline
\end{tabular}

How does the entrepreneurship tendency of SET students compare with other studies on students and professions?

Table 2 contains the results of the present study and those of other studies in literature that conducted GET tests on different student types and professions. Groups with relatively high enterprising tendencies and a total GET score of 40 and above are obtained from the SET students. These students already have a minimum of one year's experience in business, as business owners and as entrepreneurs. Other groups with a tendency higher than the average of 37 include groups of 
lecturers and MBA students. Professions with lower enterprising tendencies appear to be teachers, nurses, clerical trainees, civil servants and undergraduate students.

Four enterprising tendencies (need for achievement, creativity, risk-taking and locus of control) of SET students compare very well with those of business owners/entrepreneurs. It is interesting to note that the business owners/entrepreneurs in all the groups reported on in the literature are the only groups with a "need for autonomy" score above the average GET score of 4 . A low score for the "need for autonomy" subfield can indicate flexibility in decision-making, a facilitating nature and a preference for working for someone else instead of managing others. A respondent who attains a high score for this subfield is generally independent and a poor employee in jobs that lack autonomy. They are stubborn, determined and need independence (Caird, 2014). 
SAJESBM Volume 7 (2015)

Table 2: GET results for different student types and professions

\begin{tabular}{|c|c|c|c|c|c|c|c|}
\hline Enterprising tendency & No & $\begin{array}{l}\text { Total } \\
\text { GET } \\
\text { score }\end{array}$ & $\begin{array}{l}\text { Need for } \\
\text { achievement }\end{array}$ & $\begin{array}{l}\text { Need for } \\
\text { autonomy }\end{array}$ & $\begin{array}{l}\text { Creative } \\
\text { tendency }\end{array}$ & $\begin{array}{l}\text { Calculated } \\
\text { risk-taking }\end{array}$ & $\begin{array}{l}\text { Internal } \\
\text { locus of } \\
\text { control }\end{array}$ \\
\hline SET students & 189 & 40.00 & 9.96 & 3.26 & 9.00 & 8.99 & 8.79 \\
\hline $\begin{array}{l}\text { Students one year in } \\
\text { business }^{1}\end{array}$ & 29 & 40.41 & 10.03 & 3.17 & 9.86 & 9.14 & 8.21 \\
\hline Business owner ${ }^{2}$ & 73 & 41.04 & 9.92 & 4.14 & 8.77 & 8.75 & 9.51 \\
\hline Teacher $^{2}$ & 101 & 35.94 & 8.84 & 3.32 & 8.24 & 7.50 & 8.17 \\
\hline Nurses $^{2}$ & 33 & 33.33 & 8.52 & 2.85 & 7.97 & 6.61 & 7.76 \\
\hline Clerical trainees ${ }^{2}$ & 10 & 29.40 & 6.70 & 3.00 & 6.10 & 6.20 & 7.90 \\
\hline Civil servants ${ }^{2}$ & 20 & 33.55 & 8.45 & 3.00 & 7.70 & 6.80 & 7.50 \\
\hline Lecturers $^{2}$ & 25 & 38.28 & 8.88 & 4.12 & 8.48 & 8.64 & 8.24 \\
\hline $\begin{array}{l}\text { Australian } \\
\text { entrepreneurs }\end{array}$ & 56 & 43.05 & 10.02 & 4.05 & 9.36 & 9.30 & 10.00 \\
\hline $\begin{array}{l}\text { Australian MBA } \\
\text { students }^{3}\end{array}$ & 56 & 39.41 & 9.34 & 3.71 & 8.63 & 8.25 & 9.48 \\
\hline $\begin{array}{l}\text { Egyptian } \\
\text { undergraduates }{ }^{4}\end{array}$ & 55 & 33.00 & 7.60 & 3.25 & 8.40 & 3.60 & 8.10 \\
\hline $\begin{array}{l}\text { Engineering } \\
\text { undergraduates }\end{array}$ & 22 & 32.91 & 7.64 & 3.41 & 7.27 & 7.32 & 7.27 \\
\hline
\end{tabular}

${ }^{1}$ Van Niekerk \& Van der Lingen (2015)

${ }^{2}$ Caird (1991)

${ }^{3}$ Mazzarol (2007)

${ }^{4}$ Kirby \& Ibrahim (2011)

${ }^{5}$ Sethu (2012) 
Is the respondent's enterprising tendency related to his or her first scientific degree (BEng, BSc or BTech)?

The sig t-test results conducted for the different student groups (first degrees) for the five subfields show no statistical significance (no p-values <0.1) (see Table 3). Within the SET group of students, there is no statistical justification that the students' enterprising tendency relates to their first engineering, science or technology degree.

Table 3: P-values as determined by a two-tailed sig t-test for SET students

\begin{tabular}{|l|ll|l|}
\hline Enterprising tendency & First degree & First degree & P-value \\
\hline \multirow{4}{*}{ Need for achievement } & BEng & BSc & 0.4492 \\
& BSc & BTech & 0.3015 \\
& BTech & BEng & 0.9646 \\
\hline \multirow{4}{*}{ Creative tendency for autonomy } & BEng & BSc & 0.7153 \\
& BSc & BTech & 0.7161 \\
& BTech & BEng & 0.9429 \\
\hline \multirow{3}{*}{ Calculated risk-taking } & BEng & BSc & 0.4975 \\
& BSc & BTech & 0.7287 \\
& BTech & BEng & 0.5716 \\
\hline \multirow{3}{*}{ Internal locus of control } & BEng & BSc & 0.9850 \\
& BSc & BTech & 0.7200 \\
& BTech & BEng & 0.7065 \\
\hline \multirow{2}{*}{ Total GET score for five tendencies } & BEng & BSc & 0.6463 \\
& BSc & BTech & 0.5982 \\
& BTech & BEng & 0.2134 \\
\hline
\end{tabular}

Each tendency was further analysed by distinguishing between the scores below the GET average for each group within each enterprising tendency. The results are captured in figures 1a to 1e. It is clear from the results that, for each enterprising characteristic, comparable results were obtained for all the subfields of all SET student groups, except the "need for autonomy" subfield. A significantly higher percentage of the BEng students compared to the BSc and BTech students had an average or above-average score for "need for autonomy" (see Figure 1b). 

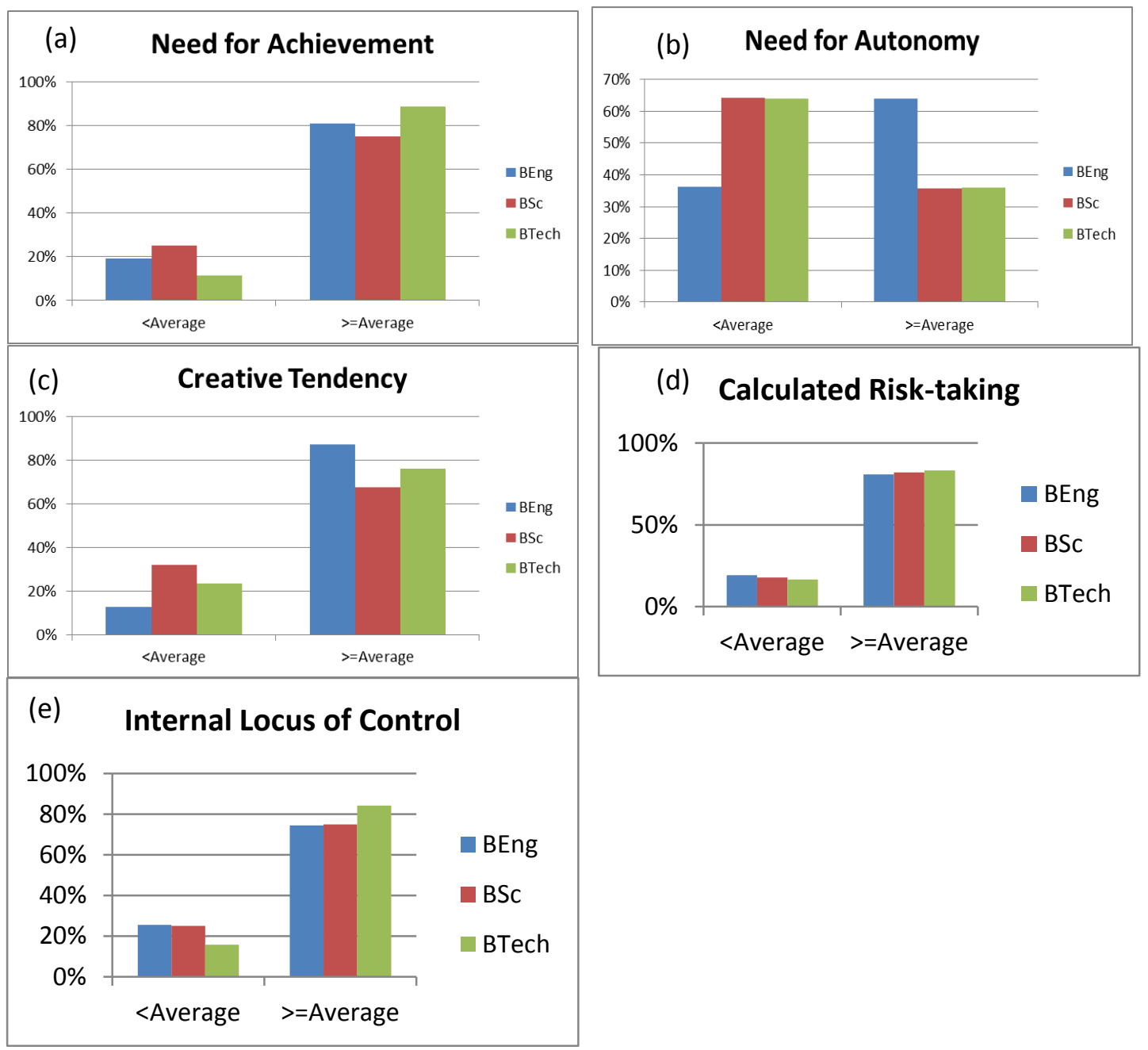

Figure 1: Comparison between the scores of SET students for the different enterprising tendencies: (a) need for achievement, (b) need for autonomy, (c) creative tendency, (d) calculated risk-taking and (e) internal locus of control

\section{Does gender influence enterprising tendency?}

Table 4 provides the sample size of the genders within the different SET groups of students, whereas Table 5 indicates the enterprising tendencies of each group according to gender.

Table 4: Gender ratio between the different SET student groups

\begin{tabular}{|l|c|c|c|}
\hline First degree & No & Male, No (\%) & Female, No (\%) \\
\hline BEng & 47 & $36(77 \%)$ & $11(23 \%)$ \\
\hline BSc & 28 & $17(61 \%)$ & $11(39 \%)$ \\
\hline BTech & 114 & $84(74 \%)$ & $30(26 \%)$ \\
\hline Total & 189 & $137(72 \%)$ & $52(28 \%)$ \\
\hline
\end{tabular}


The total GET score for all the SET groups are statistically significant with a p-value of $<0.05$ between males and females, and the males showing a higher enterprising tendency. For a number of years, Global Entrepreneurship Monitor (GEM) studies (Turton \& Herrington, 2014) have shown that males are more likely to pursue entrepreneurial careers than females. Shinnar, Hsu and Powell (2014) found that attending an entrepreneurial course results in a statistically significant increase in entrepreneurial self-efficacy (ESE) for male students when compared to female students.

The highest statistical significance was observed for the need for autonomy tendency in the BTech group with a significance of $p<0.001$. Other noticeable statistically significant results for gender were found at a significance of $p<0.1$ for the total SET group in terms of need for autonomy and creative tendency, as well as internal locus of control in the BTech degree group. There is a statistical significance of $p<0.05$ for calculated risk-taking for the BTech group and internal locus of control for all SET groups. Thus, in the BTech group specifically, it appears that males have a much higher need for autonomy, as well as a higher creative tendency, calculated risk-taking and internal locus of control than females. No statistically significant results with regard to gender were obtained for the BEng and BSc groups. 
SAJESBM Volume 7 (2015)

Table 5: The means and standard deviations for SET students based on enterprising tendency measurements per gender

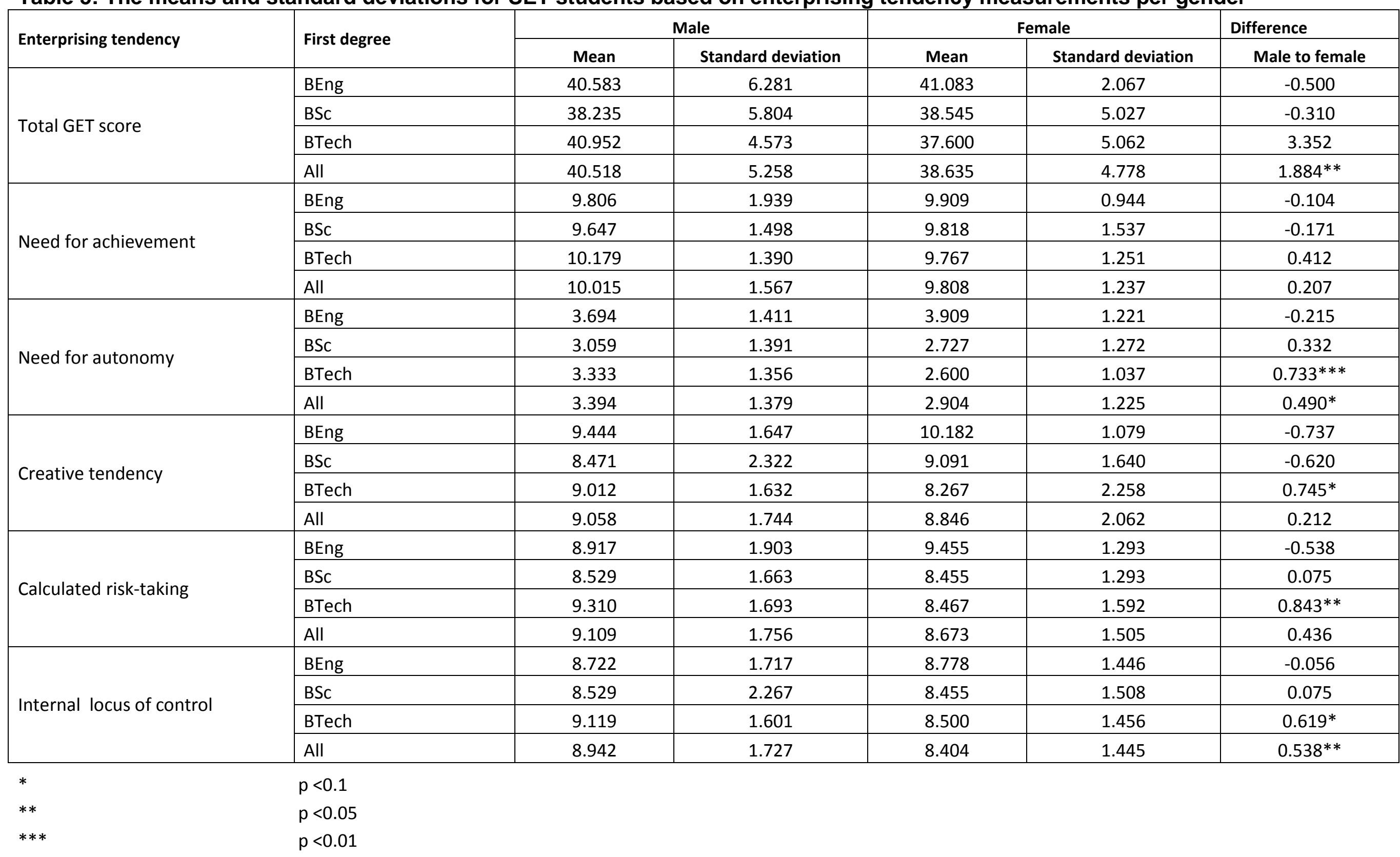




\section{Do ethnic groups have an influence on enterprising tendency?}

The South African population is generally divided into four ethnic groups: white, black, coloured and Indian. The sample size for each of these ethnic groups within the SET group is shown in Table 6 . Due to the small sample for the coloured and Indian student groups in the present study, further analyses only include the white and black student groups (see Table 7). Antonites and Govindasamy (2013) conducted a study on the critical success factors of Indian entrepreneurs. Preisendörfer, Bitz and Bezuidenhout (2012) found a vast difference in the total early-stage entrepreneurial activity (TEA) rates of the four ethnic groups in South Africa with lower rates for black and coloured South Africans (4.3\% and 2.9\% respectively) when compared to the rates of $13.2 \%$ for the white and $16.1 \%$ for the Indian student groups. As the black population is the largest group in South Africa at $79.2 \%$ of the population according to Census 2011 (StatsSA, 2012), it affects the country's weak overall TEA performance.

Table 6: Sample size of ethnic groups within the different SET student groups

\begin{tabular}{|l|c|c|c|c|}
\hline First degree & White, No & Black, No & Coloured, No & Indian, No \\
\hline BEng & 21 & 24 & 1 & 1 \\
\hline BSc & 4 & 21 & 0 & 1 \\
\hline BTech & 15 & 90 & 3 & 5 \\
\hline Total & 40 & 135 & 4 & 7 \\
\hline
\end{tabular}

No statistical significance exists for the total GET scores between these two ethnic groups. For the subfields, statistically significant results $(p<0.05)$ with a higher tendency towards the white student group include need for autonomy, calculated risktaking and internal locus of control. Mueller and Thomas (2001) have shown that there is a link between the willingness to take risks and internal locus of control. In their study, Preisendörfer et al. (2012) showed that black student groups have a low level of self-confidence and a tendency to avoid risks, which includes a high fear of failure.

The only statistically significant result was that the black groups showed a higher statistically significant entrepreneurial characteristic for the subfield "need for achievement" ( $p<0.1)$. The black student groups have higher "need for achievement" tendency scores for all three SET groups (BEng, BSc and BTech students). 
Table 7: The means and standard deviations for SET students based on enterprising tendency measurements per ethnic group (white and black)

\begin{tabular}{|c|c|c|c|c|c|c|}
\hline \multirow{2}{*}{$\begin{array}{l}\text { Enterprising } \\
\text { tendency }\end{array}$} & \multirow{2}{*}{ First degree } & \multicolumn{2}{|c|}{ White } & \multicolumn{2}{|c|}{ Black } & \multirow{2}{*}{$\begin{array}{c}\begin{array}{c}\text { Difference } \\
\text { between }\end{array} \\
\begin{array}{c}\text { white and } \\
\text { black }\end{array} \\
\end{array}$} \\
\hline & & Mean & $\begin{array}{l}\text { Standard } \\
\text { deviation }\end{array}$ & Mean & $\begin{array}{l}\text { Standard } \\
\text { deviation }\end{array}$ & \\
\hline \multirow{4}{*}{$\begin{array}{l}\text { Total GET } \\
\text { score }\end{array}$} & BEng & 40.238 & 5.787 & 42.174 & 4.754 & -1.936 \\
\hline & BSC & 41.500 & 2.380 & 37.917 & 5.587 & 3.583 \\
\hline & BTech & 41.267 & 5.120 & 39.912 & 5.026 & 1.355 \\
\hline & All & 40.750 & 5.227 & 39.942 & 5.198 & 0.808 \\
\hline \multirow{4}{*}{$\begin{array}{l}\text { Need for } \\
\text { achievement }\end{array}$} & BEng & 9.476 & 1.861 & 10.391 & 1.530 & $-0.915^{*}$ \\
\hline & $\mathrm{BSC}$ & 9.500 & 1.732 & 9.708 & 1.517 & -0.208 \\
\hline & BTech & 9.667 & 1.839 & 10.088 & 1.297 & -0.421 \\
\hline & All & 9.550 & 1.797 & 10.072 & 1.381 & $-0.522 *$ \\
\hline \multirow{4}{*}{$\begin{array}{l}\text { Need for } \\
\text { autonomy }\end{array}$} & BEng & 3.714 & 1.347 & 3.783 & 1.476 & -0.068 \\
\hline & $\mathrm{BSC}$ & 3.500 & 1.291 & 2.958 & 1.301 & 0.542 \\
\hline & BTech & 3.733 & 1.486 & 3.055 & 1.259 & $0.678^{*}$ \\
\hline & All & 3.700 & 1.363 & 3.159 & 1.325 & $0.541^{* *}$ \\
\hline \multirow{4}{*}{$\begin{array}{l}\text { Creative } \\
\text { tendency }\end{array}$} & BEng & 9.190 & 1.601 & 10.217 & 1.204 & $-1.027^{* *}$ \\
\hline & $\mathrm{BSC}$ & 9.750 & 1.258 & 8.750 & 2.027 & 1.000 \\
\hline & BTech & 8.333 & 1.952 & 9.011 & 1.773 & -0.678 \\
\hline & All & 8.925 & 1.745 & 9.167 & 1.794 & -0.242 \\
\hline \multirow{4}{*}{$\begin{array}{l}\text { Calculated } \\
\text { risk-taking }\end{array}$} & BEng & 9.000 & 1.871 & 9.261 & 1.738 & -0.261 \\
\hline & $\mathrm{BSC}$ & 9.500 & 1.291 & 8.292 & 1.517 & 1.208 \\
\hline & BTech & 9.667 & 1.291 & 9.000 & 1.795 & 0.667 \\
\hline & All & 9.300 & 1.620 & 8.920 & 1.755 & $0.380 * *$ \\
\hline \multirow{4}{*}{$\begin{array}{l}\text { Internal locus } \\
\text { of control }\end{array}$} & BEng & 8.857 & 1.276 & 8.522 & 1.563 & 0.335 \\
\hline & $\mathrm{BSC}$ & 9.250 & 0.957 & 8.208 & 2.021 & 1.042 \\
\hline & BTech & 9.867 & 1.125 & 8.758 & 1.622 & $1.108 * *$ \\
\hline & All & 9.275 & 1.261 & 8.623 & 1.688 & $0.652 * *$ \\
\hline$*$ & \multicolumn{6}{|l|}{$p<0.1$} \\
\hline$* *$ & \multicolumn{6}{|l|}{$p<0.05$} \\
\hline$* * *$ & \multicolumn{6}{|l|}{$p<0.01$} \\
\hline
\end{tabular}

\section{What is the students' perceived accuracy of the GET test?}

After completing the survey, respondents were asked to rate the perceived accuracy of the feedback, based on the enterprising tendency scores they received. The response was generally favourable, with $71 \%$ of respondents considering the test to be "accurate" and "very accurate". While the accuracy of the respondents' selfperception on their enterprising tendencies is not a scientific measure, it provides a level of confidence in the GET test's ability to measure accurately. 


\section{LIMITATIONS OF THE STUDY}

The research was conducted on students studying towards the honours degree at the University of Pretoria's GSTM that included the Technological Entrepreneurship module. Therefore, the sample is limited to one entrepreneurship module at a single university, which could influence the relevance to other SET students. Future research should make use of a larger sample of SET students and/or employees, which will provide a better understanding of this group's enterprising tendencies. This research could further enable entrepreneurship programmes to be more effective in training SET groups to have a higher impact.

\section{CONCLUSIONS}

The study was conducted on the honours students enrolled for the Technological Entrepreneurship module at the University of Pretoria. All respondents had a first degree in science, engineering or technology. Literature on the enterprising tendency of technopreneurs or intended entrepreneurs with a background in science, engineering and technology is limited.

The study indicates that the respondents have an above-average enterprising tendency for the total GET score, as well as for four of the five subfields. The SET students' total GET score of 40 indicates that they will most likely be satisfied with being intrapreneurs who are part of a team within a corporation. The group has strengths in four of the five enterprising characteristics. A lower-than-average score was obtained for the subfield "need for autonomy". Because of the above-average enterprising characteristics in most of the subfields, the respondents are likely to be enterprising in some way, but most likely through intrapreneurship (Caird, 2014).

Comparison of GET results from studies conducted on other student groups and professions reveals a comparable overall enterprising tendency of SET students with existing entrepreneurs and business owners. Again, SET students scored lower in the subfield "need for autonomy" than the entrepreneurs and even some of the other student groups, such as MBA and undergraduate students, as well as professions, such as lecturers and teachers. 
SET students' first degree (BEng, BSc or BTech) appears to have no influence on their enterprising tendency, as no statistically significant results were obtained. However, further investigation into the enterprising characteristics or subfields revealed that the BEng students have a remarkably higher "need for autonomy" when compared to the BSc and BTech student groups.

The results show that males have a higher enterprising tendency than females. At a statistical significance of $p<0.001$, the results further indicated that males within the BTech group have a significantly higher need for autonomy than females in the same group. Other statistically significant results for this group indicated that males had a stronger tendency towards creativity, calculated risk-taking and internal locus of control than females. No statistically significant results were obtained for the BSc and BEng groups on the influence of gender on enterprising tendency.

The enterprising tendency study in relation to the ethnic groups shows that the white student group has a statistically $(p<0.05)$ higher propensity for the subfields "need for autonomy", "calculated risk-taking" and "internal locus of control" when compared to the black student group. Mueller and Thomas (2001) indicate that there is a link between willingness to take risks and internal locus of control. Other authors, such as Preisendörfer et al. (2012), have also found that black student groups have a lower level of self-confidence, which relates to the subfield "locus of control". It indicates an external locus of control where the respondent doubts personal qualities and efforts to achieve goals in life and rather believes in fate (Caird, 2014). Preisendörfer et al. (2012) also found that the black student groups tend to avoid risks due to, for example, fear of failure. On the other hand, the black student groups had a higher tendency for the subfield "need for achievement" in relation to the white student groups ( $p<0.1$ ). Interestingly, the black student groups had higher scores for the subfield "need for achievement" for all three SET groups (BEng, BSc and BTech).

In 2014, South Africa had an unemployment rate of $25.1 \%$, which could escalate to the $8^{\text {th }}$ highest unemployment rate in the world by 2015 . This rate includes a youth unemployment rate of 52.5\% (World Employment Social Outlook, 2015). One of the 2013 GEM findings reveals that the number of young people in South Africa who believe that they have the entrepreneurial skills required to start a successful business 
is also significantly less than in most other developing countries (Turton \& Herrington, 2014). The South African population consists of approximately $80 \%$ black people and, in order to grow the economy and alleviate problems associated with unemployment and poverty, the country depends on this ethnic group to become entrepreneurs and set up new ventures.

Entrepreneurial traits need to be developed already at an early age, such as at primary - and secondary school levels (Ahmad, 2013; Marques et al., 2012; Draycott et al., 2011). However, a better understanding of tertiary students' entrepreneurship tendency could enable lecturers to develop courses that can stimulate entrepreneurial traits in order to enhance the potential for new venture creation.

\section{REFERENCES}

Ahmad, S. Z. 2013. The need for inclusion of entrepreneurship education in Malaysia lower and higher learning institutions, Education + Training, 55(2):191 - 203

Ajzen, I. 1991. The theory of planned behaviour. Organisational Behaviour and Human Decision Processes, 50(2):179-211.

Antonites, A. \& Govindasamy, T. 2013. Critical success factors of Indian entrepreneurs. Southern African Journal of Entrepreneurship and Small Business Management, 6:115-133.

Autio, E. 2005. Global Entrepreneurship Monitor: 2005 report on high expectation entrepreneurship. London; Babson Park, MA: London School of Business; Mazars and Babson.

Briggs-Myers, I. \& McCaulley, M.H. 1985. Guide to the development and use of the Myers-Briggs type indicator. Palo Alto, CA: Consulting Psychologists Press.

Caird, S. 1991a. Testing enterprising tendency in occupational groups. British Journal of Management, 2(4): 177-186.

Caird, S. 1991b. The enterprising tendency of occupational groups. International Small Business Journal, 9(4):75-81.

Caird, S. 1993. What do psychological tests suggest about entrepreneurs? Journal of Managerial Psychology, 8(6):11-20.

Caird, S. 2006. General Measure of Enterprising, Tendency version 2 (GET2). In: T. Mazzarol, Entrepreneurship and Innovation. Ashwood: Tilde University Press.

Caird, S. 2014. General Enterprising V2 Test. Available from: http://get2test.net/. 
[Accessed on 10 January 2014].

Carey, C. \& Matlay, H. 2010. Creative disciplines education: a model for assessing ideas in entrepreneurship education? Education and Training, 52(8/9):694-709.

Cromie, S. 2000. Assessing entrepreneurial inclinations: some approaches and empirical evidence. European Journal of Work and Organisational Psychology, 9(1):7-30.

Demirci, A. 2013. Cross-cultural differences in entrepreneurial tendencies: an exploratory view in Turkey and Canada. International Journal of Entrepreneurship, 17:21-40.

Draycott, M. C., Rae, D. \& Vause, K. 2011. The assessment of enterprise education in the secondary education sector: A new approach?, Education + Training, 53(8/9):673 -691 .

Drucker, P. 1985. Innovation and entrepreneurship. London: Heinemann.

Edwards, A.L. 1959. Manual for the Edwards personal preference schedule. New York, NY: The Psychological Corporation.

Farrington, S.M., Venter, D.J.L. \& Neethling, A. 2012. Entrepreneurial attributes and intentions: perceptions of South African business science students. Management Dynamics, 21(3):17-33.

Gabor, D. 1970. Innovations: scientific, technical and social. Oxford: Oxford University Press.

Hébert, R.F. \& Link, A.N. 1989. In search of the meaning of entrepreneurship. Small Business Economics, 1:39-49.

Huber, L.R., Sloof, R. \& Van Praag, M. 2014. The effect of early entrepreneurship education: evidence from a field experiment. European Economic Review, 72:76-97.

Ishiguro, J. 2014. What influences entrepreneurial career choice? An exploratory analysis of the Sally Caird's GET2 for Japanese high school students. Proceedings of the Academy of Entrepreneurship, Nashville, 20(1): 9-13.

Jackson, D.N. 1976. Jackson personality inventory manual. Goshen, NY: Research Psychologists Press.

Jyohti, P. 2009. Revisiting linkages between entrepreneurship and higher education. Advances in Management, 2(10):39-43.

Karlsson, T. \& Moberg, K. 2013. Improving perceived entrepreneurial abilities through education: exploratory testing of an entrepreneurial self efficacy scale in a pre-post setting. The International Journal of Management Education, 11(1):1-11. 
Kautonen, T., Van Gelderen, M. \& Tornikoski, E. 2013. Predicting entrepreneurial behaviour: a test of the theory of planned behaviour. Applied Economics, 45(6):697707.

Keat, O., Yeng, S.C. \& Meyer, D. 2011. Inclination towards entrepreneurship among university students: an empirical study of Malaysian university students. International Journal of Business and Social Science, 2(4):206-220.

Kirby, D. \& Ibrahim, N. 2011. Entrepreneurship education and the creation of an enterprise culture: provisional results from an experiment in Egypt. International Entrepreneurship and Management Journal, 7(2):181-193.

Kirby, D. 2004. Entrepreneurship education: can business schools meet the challenge? Education and Training, 46(8):510-519.

Koh, H.C. 1996. Testing hypotheses of entrepreneurial characteristics: a study of Hong Kong MBA students. Journal of Managerial Psychology, 11(3):12-25.

Krueger, N.F., Reilly, M.D. \& Carsrud, A.L. 2000. Competing models of entrepreneurial intentions. Journal of Business Venturing, 15:411-432.

Kuratko, D.F. 2005. The emergence of entrepreneurship education: development, trends, and challenges. Entrepreneurship Theory and Practice, 29(5):577-597.

Liñán, F. \& Chen, Y.W. 2009. Development and cross-cultural application of a specific instrument to measure entrepreneurial intentions. Entrepreneurship Theory and Practice, 33(3):593-617.

Martin, B.C., McNally, J.J. \& Kay, M.J. 2013. Examining the formation of human capital in entrepreneurship: a meta-analysis of entrepreneurship education outcomes. Journal of Business Venturing, 28:211-224.

Marques, C-S., Ferreira, J-J., Gomes, D.N. \& Rodriques, T.G. 2012. Entrepreneurship education: How psychological, demographic and behavioural factors predict the entrepreneurial intention. Education + Training, 54 (8/9):657-672.

Mazzarol, T. 2007. Awakening the entrepreneur: an examination of Entrepreneurial orientation among MBA students. Proceedings of the EFMD 37th Entrepreneurship, Innovation and Small Business (EISB) Annual Conference, pp.1-15.

McClelland, D., Atkinson, J., Clark, R. \& Lovell, E. 1953. The achievement motive. New York, NY: Appleton-Century-Crofts.

McMillan, J. \& Schumacher, S. 2006. Research in education: evidence-based inquiry. Upper Saddle River, NJ: Pearson Education. 
Mueller, S.L. \& Thomas, A.S. 2001. Culture and entrepreneurial potential: a nine country study of locus of control and innovativeness. Journal of Business Venturing, 16(1):51-75.

Mumford, A. \& Honey, P. 1992. Questions and answers on learning styles questionnaire. Industrial and Commercial Training, 24(7):10-13.

Murray, H.A. 1943. Thematic Apperception Test. Cambridge, MA: Harvard University Press.

Mwasalwiba, E.S. 2010. Entrepreneurship education: a review of its objectives, teaching methods, and impact indicators. Education and Training, 52(1):20-47.

Nieuwenhuizen, C. \& Groenewald, D. 2006. Level of creativity and risk among successful entrepreneurs. Southern African Business, pp. 70-90.

Nieuwenhuizen, C. \& Groenewald, D. 2008. Entrepreneurs' learning preferences: a guide for entrepreneurship education. Acta Commercii, pp. 128-144.

Preisendörfer, P., Bitz, A. \& Bezuidenhout, F.J. 2012. In search of black entrepreneurship: why is there a lack of entrepreneurial activity among the black population in South Africa? Journal of Developmental Entrepreneurship, 17(1):1250006(1-18).

Pretorius, M. 2008. Assessment of entrepreneurship education: a pilot study. Southern African Journal of Entrepreneurship and Small Business Management, 1(1):1-20.

Radipere, S. 2012. South African university entrepreneurship education. African Journal of Business Management, 6(44):11015-11022.

Refaat, A. 2009. The necessity of engineering entrepreneurship education for developing economies. International Journal of Education and Information Technologies, 2(3):85-96.

Rotter, J.B. 1966. Generalised expectancies for internal versus external control reinforcement. Psychological Monographs: General and Applied, 80(609).

Schumpeter, J.A. 1951. Change and the entrepreneur. In: R.V. Clemence (Ed.), Essays of J.A. Schumpeter. Boston, MA: Addison-Wesley.

Sethu, H.S. 2012. Study of entrepreneurial tendencies in Manipal University students based on GETT. Voice of Research, 1(2):78-83.

Shane, S. \& Venkataraman, S. 2000. The promise of entrepreneurship as a field of research. The Academy of Management Review, 25(1):217-226. 
Shinnar, R.S., Hsu, D.K. \& Powell, B.C. 2014. Self-efficacy, entrepreneurial intentions, and gender: assessing the impact of entrepreneurship education longitudinally. The International Journal of Management Education, 12:561-570.

Souitaris, V., Zerbinati, S. \& Al-Laham, A. 2007. Do entrepreneurship programmes raise entrepreneurial intention of science and engineering students? The effect of learning, inspiration and resources. The Journal of Venturing, 22(4):566-591.

StatsSA 2012. Census 2011: Census in brief. Pretoria: Statistics South Africa (StatsSA). Available from: http://www.statssa.gov.za/publications/p03014/ p030142011.pdf. [Accessed on 12 August 2014].

Stormer, F. \& Kline, T. 1999. Measuring entrepreneurship with the General Enterprising Tendency (GET) test: criterion-related validity and reliability. Human Systems Management, 18:47-52.

Turton, N. \& Herrington, M. 2014. Global Entrepreneurship Monitor: South Africa 2013 report. Cape Town: The Centre for Innovation and Entrepreneurship, Graduate School of Business, University of Cape Town.

Van Niekerk, G. \& Van der Lingen, E. 2015. Does management education affect the entrepreneurial tendency of students? Submitted for publication in Proceedings of the IAMOT 2015 Conference, 8-11June.

Van Praag, C.M. 1999. Some classic views on entrepreneurship. De Economist, 147(3):311-335.

Van Vuuren, J.J. \& Nieman, G.H. 1999. Entrepreneurial education and training: a model for syllabi/curriculum development. Paper presented at the 45th World Conference of the International Conference for Small Business, Naples, Italy, 6-9 June, pp.1-17.

Warhuus, J.P. \& Basaiawmoit, R.V. 2014. Entrepreneurship education at Nordic technical higher education institutions: comparing and contrasting program designs and content. The International Journal of Management Education, 12:317-332.

Welman, C. Kruger, F. \& Mitchell B. 2005. Research methodology. Cape Town: Oxford University Press.

Wennekers, S. \& Thurik, R. 1999. Linking entrepreneurship and economic growth. Small Business Economics, 13(1):27-56.

Wickham, P.A. 1998. Strategic entrepreneurship: a decision-making approach to new venture creation and management. 2nd ed. London: Prentice Hall. 
SAJESBM Volume 7 (2015)

World Employment Social Outlook, 2015. World Employment Social Outlook Trends 2015. Geneva: International Labour Organisation. 